\title{
INTEGRATED ANALYSIS OF FOREST POLICIES AND THEIR IMPACTS ON LANDSCAPE AND LIFESCAPE DYNAMICS: A CASE STUDY IN THE
}

\section{WALANAE FOREST MANAGEMENT UNIT, INDONESIA}

\author{
TAJUDDIN $^{1}$, SUPRATMAN $^{2}$, DARMAWAN SALMAN $^{3}$, YUSRAN YUSRAN $^{2}$, \\ MUHAMMAD ALIF K. SAHIDE ${ }^{2}$ \\ ${ }^{1}$ Doctoral Student at the Graduate Program of Hasanuddin University (UNHAS), \\ Makassar, Indonesia/Production Forest Management Agency Regional XIII Makassar, \\ Directorate General of Sustainable Management of Production Forest, Ministry of \\ Environment and Forestry, \\ ${ }^{2}$ Laboratory on Forest Policy and Entrepreneurship, Faculty of Forestry, Hasanuddin \\ University (UNHAS), Makassar, Indonesia \\ ${ }^{3}$ Department of Social Economics, Faculty of Agriculture, Hasanuddin University \\ (UNHAS), Makassar, Indonesia \\ *Corresponding author e-mail: muhammad.alif@unhas.ac.id
}

Received: $23^{\text {th }}$ October 2018 , Accepted: $2^{\text {nd }}$ January 2019

\begin{abstract}
In the past few decades, forest policies have caused changes in forest landscape and community lifescape in the study area of Walanae Forest Management Unit (KPH Walanae), South Sulawesi Province. This research aims to analyze forest policy dynamics and their impacts on landscape and lifescape dynamics. We quantify landscape dynamics using land use and land cover change and landscape metrics in interpreting remote sensing results of four data sets obtained in 1990, 2000, 2009, and 2016. Furthermore, we investigate lifescape dynamics using qualitative/quantitative description. We found a rapid land use change in forest landscapes within the past 26 years. A significant change showed that, in 1990-2000, the primary forest that changed into the secondary forest and shrubs has changed into dry land agriculture mix shrubs. The decreased area of the forest brought an increase in economic income for people on one side and large disturbances and forest fragmentation on the other. Various forest policies influenced the forest composition and cover but were insufficiently successful in protecting the natural forest. Results showed that several forest policies that considerably impact the landscape and lifescape conditions include forest land designation, industrial forest plantation, and restoration activities. The policies on establishing KPH and social forest program have not shown the maximum result on the landscape and lifescape improvements and, therefore, must be supported.
\end{abstract}

Keywords: land use and land cover change, landscape metrics, social forestry

\section{INTRODUCTION}

The world faces a global challenge on a significant increase in tropical forest degradation and deforestation within the past decades (Mustard et al., 2004; Southworth et al., 2012). 
Tajuddin et.al.: Integrated analysis of forest policies and their impacts on landscape and lifescape dynamics: a case study in the Walanae Forest Management Unit, Indonesia

Forest policies have become a major cause in land use and land cover change (LULCC) (Geist \& Lambin, 2002; Hersperger \& Bürgi, 2010; Chavez, 2014; Günter et al., 2015; Garcia \& Ballester, 2016) and community lifescape change (Dhakal et al., 2012; Loxton et al., 2014; Yusran et al., 2017). This condition is due to forest policies play important roles in guiding activities implemented in forest management (Geist et al., 2006; Yasmi et al., 2010; OECD, 2010; Grebner et al., 2013) and impact the local environment and community welfare (Gibbes et al., 2017).

Field facts show that forest policies are not configured well for managing ecological issues (Spies et al., 2007) and disregard the socioeconomic situation of rural communities (Dotzauer, 1993). Therefore, a shift in policies and forest management is requires to create sustainable forest management (Chavez, 2014; Günter et al., 2015; Sewnet, 2015). Such management requires a comprehensive understanding of the driving factors of land use change, its process, and its effects in a specific location prior to implementing policies (Geist \& Lambin, 2002; Mutoko et al., 2014; Günter et al., 2015; Legaard et al., 2015). An analysis of LULCC and landscape pattern is effective for sustainable forest management because the results show the interaction between anthropogenic activities and the environment (Alphan et al., 2009; Linh et al., 2012; Avanzini et al., 2016). Furthermore, an overview is provided for the impact of forest policies on forest landscape condition (Menon et al., 2008) and community lifescape (Turner, 1989; Käyhkö et al., 2015).

In this research, landscape is defined as a particular configuration of a combination of topography, vegetation, land use, and settlement patterns that limit the coherence of various natural processes, cultures, and human activities (Maryani et al., 2014); by contrast, lifescape or human dimension covers economic, cultural, and social aspect interaction within the physical and biological dimension from the ecosystem (Hargrove et al., 2000; Veisi et al., 2012). The forest landscape boundaries are based on the working area boundaries of KPH Walanae, which is located in the Wajo and Soppeng districts.

We used an integrated approach that considers various disciplines, data sources, and constructed methods for analyzing LULCC (Mutoko et al., 2014). This research aims to analyze the forest policies implemented in $\mathrm{KPH}$ Walanae and their impacts on forest landscape and community lifescape. We applied cross-discipline approaches, which integrate policy dynamics, results of remote sensing interpretation, statistical data related to lifescape dynamics, data based on interview, and field observation. We used four sets of data from the results of remote sensing interpretation in 1990, 2000, 2009, and 2016 to produce LULCC maps and landscape metrics. These data are equipped with primary data from field observations and interviews with informants and secondary statistical data. We analyzed the change in forest policies to quantify the impact on forest landscape and community lifescape.

\section{MATERIALS AND METHODS}

\section{Description of the study area}

The research was conducted in the KPH Walanae working area, which is located in the Soppeng and Wajo districts. The total area of KPH Walanae is approximately 65,484 ha, which consists of 40,522 ha of protected forest (HL), 13,373 ha of production forest (HP), and 11,589 ha of limited forest production (HPT) (Fig. 1).

The KPH Walanae working area is located between longitude $119^{\circ} 42^{\prime} 23.16^{\prime \prime} \mathrm{E}$ to $120^{\circ} 26^{\prime}$ 27.17" E and latitude $3^{\circ} 39^{\prime} 48.82^{\prime \prime} \mathrm{S}$ to $4^{\circ} 32^{\prime} 46.46^{\prime \prime} \mathrm{S}$. Elevation range is between 2 and $1500 \mathrm{~m}$ above sea level. The livelihood in the Soppeng and Wajo districts are dominated by agricultural activities with rice as the primary crop and other secondary crops, such as maize, soy bean, and mung bean. Plantation commodities include candlenuts, cacao, coconut, and 
cashew. In addition to agriculture, the majority of the community in KPH Walanae raises cattle as the primary livestock (BPS-Statistics of Soppeng Regency, 2017; BPS-Statistics of Wajo Regency, 2017).

Fig. 1: Study area of KPH Walanae.

HL : Protected Forest, HK : Conservation Forest, HP : Production Forest, HPT : Limited Production Forest.

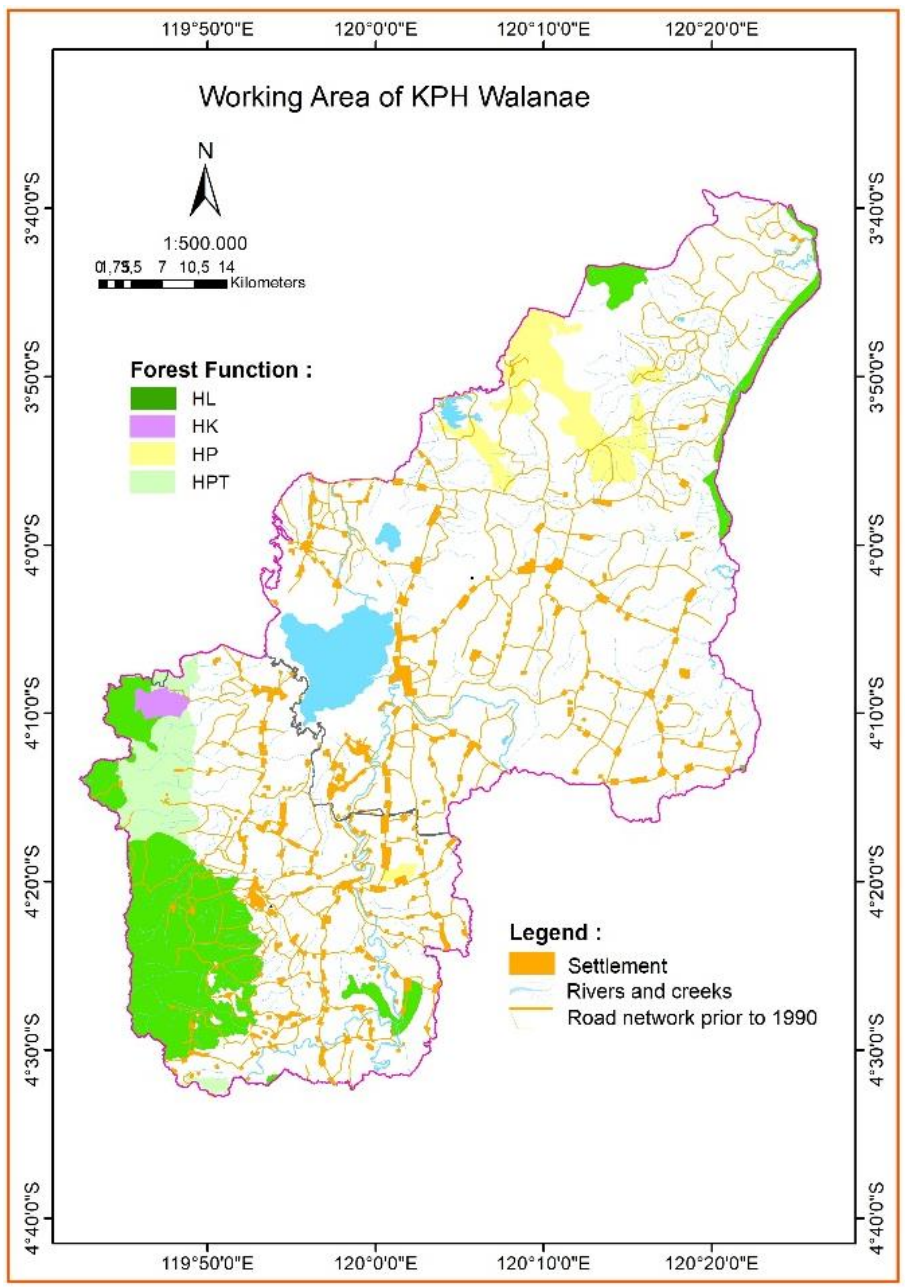

\section{Analysis of forest policy dynamics}

The change in forest area was analyzed to understand the dynamics of forest land use and area change, and the forest policy dynamics on forest utilization is used to illustrate the existing forest management and utilization. The secondary data collection uses a historical approach from literature and available government documents (Aravindakshan, 2011). Twelve people were interviewed as key resources; these relevant parties were considered involved/knowledgeable on forest policy dynamics, such as former employees ( 2 people), forest service staff ( 5 people), and communities living within and surrounding the forest area (5 people). 
Tajuddin et.al.: Integrated analysis of forest policies and their impacts on landscape and lifescape dynamics: a case study in the Walanae Forest Management Unit, Indonesia

\section{Analysis of landscape dynamics}

Landscape dynamics was analyzed to examine the impact of forestry policies on landscape change in KPH Walanae in accordance with LULCC analysis and landscape characteristics. We used a map of forest cover change in the past 26 years on the basis of remote sensing interpretation using Landsat 7 ETM+. The map was published by the Ministry of Environment and Forestry for 1990, 2000, 2009, and 2016. We used vector data with *.shp file format for these land cover maps. The data were analyzed using Geographic Information System (GIS) with ArcGIS 10.1 software to select the study area and the initial management prior to further processing to define the structural characteristics of the landscape.

The remote sensing interpretation on the land cover class used the Indonesian National Standard in interpreting an optic image with medium resolution. The Ministry of Environment and Forestry used the following units: primary dry land forest (Hp), secondary dry land forest/logged over area (Hs), shrubs (B), and dry land agriculture mix shrubs (Pc). These units were also used in our analyses. Furthermore, the standard included plantation forest $(\mathrm{Ht})$, dry land agriculture $(\mathrm{Pt})$, ponds $(\mathrm{Tm})$, paddy field $(\mathrm{Sw})$, grassland $(\mathrm{S})$, secondary mangrove forest/logged over area (Hms), water bodies (A), bare land (T), settlement/developed area (Pm), shrubby wetland (Br), and cloud-covered land ( $\mathrm{Aw})$. These areas were lumped into other land cover class in the present research.

Landscape structure was measured using Fragstats program 4.2.1 because this program offers a comprehensive selection of landscape metrics (McGarigal \& Marks, 1995). We used six landscape parameters, namely, class area (CA), percentage of landscape (PLAND), number of patch (NP), patch density (PD), largest patch index (LPI), and total edge (TE).

\section{Analysis of lifescape dynamics}

Lifescape dynamics was analyzed to demonstrate the impact of forest policy implementation on the community lifescape, especially on the community living within or nearby the forest area. In this research, we analyzed four parameters of lifescape, that is, livelihood/occupation, agricultural crop/forestry production, land tenure, and income (using gross regional domestic product approach). These parameters have been selected on the basis of a review of previous studies related to socioeconomic characteristics (lifescape) (Amoroso et al., 2004; Fitzsimons \& Cherry, 2008; Dhakal et al., 2012; Mutoko et al., 2014; Abdullah et al., 2016; Shuyu et al., 2017).

The lifescape characteristics were derived from primary and secondary data. The focus is to utilize the sources of secondary data and gain support from primary data (Dhakal et al., 2012). KPH Walanae has adequately large areas. Thus, primary data collection was conducted using a sampling in the following three villagesSering, Patampanua (Soppeng district), and Minangatellue (Wajo district). The village selection was performed through purposive method because the community in these villages are located within the forest area and has been given permission for a social forestry scheme (HKm, HTR, and partnership). The secondary data were derived from the forestry office and BPSs of South Sulawesi province, Soppeng district, and Wajo districts, and from related research. The primary data were collected through interviews with 26 informants, which consist of village authorities (4 people), farmer ( 9 people), social forest coach (1 person), Non Government Organization (NGO) (2 people), forestry staff (10 people), and the result of field observation. A data analysis related to lifescape parameters was conducted using qualitative and quantitative descriptive analyses. 


\section{RESULT}

\section{Dynamics of forest policy}

\section{Evolution of the forest area}

According to the decree of the Agricultural Ministry, the forest land designation in South Sulawesi province began in 1982. This forest land designation has been approved by various related institutions that are concerned with the land use and utilization in South Sulawesi province and is known as the Forest Land Use Agreement (TGHK). An overlay between land use planning (RTRWP) and TGHK was conducted in 1999, and the result was a decree of the Ministry of Forestry and Plantation on forest land designation in South Sulawesi province. In 2009, another review on land use was carried out in South Sulawesi province and resulted in a decree of the Ministry of Forestry on designating forest and marine areas. This research was used for adjusting the forest area after establishing West Sulawesi, which was a newly recognized province from the fission of South Sulawesi provinces. This decree remains valid, although the review process of land use has ended in 2017.

Since 1982, the dynamics of forest area designation has shown changes in the total forest area and function in South Sulawesi, including our research site (Figures 2 and 3). The decrease in forest area in 1999, when compared to 1982, was caused by land use change to an area for other purposes (APL). In 2009, the total area increased because the area, which was designated as an APL, was reintroduced as a forest area. This area was smaller than that in 1982. In addition to the change in total forest area, a total area alteration in each forest function was observed. Figures 2 and 3 illustrate that the HL was changed from 67,899 ha in 1982 to 40,594 ha in 1999 and 38,895 ha in 2009. The forest area with HPT function decreased in 1999 and 2009, whereas the forest area with HP function increased in 2009. The dynamics of land function alteration emerged with the increased status of the land to conservation forest (HK) with a total area of 1,574 ha in 2009.

Fig. 2: Map of forest area change in 1982, 1999 and 2009. For captures see Fig. 1

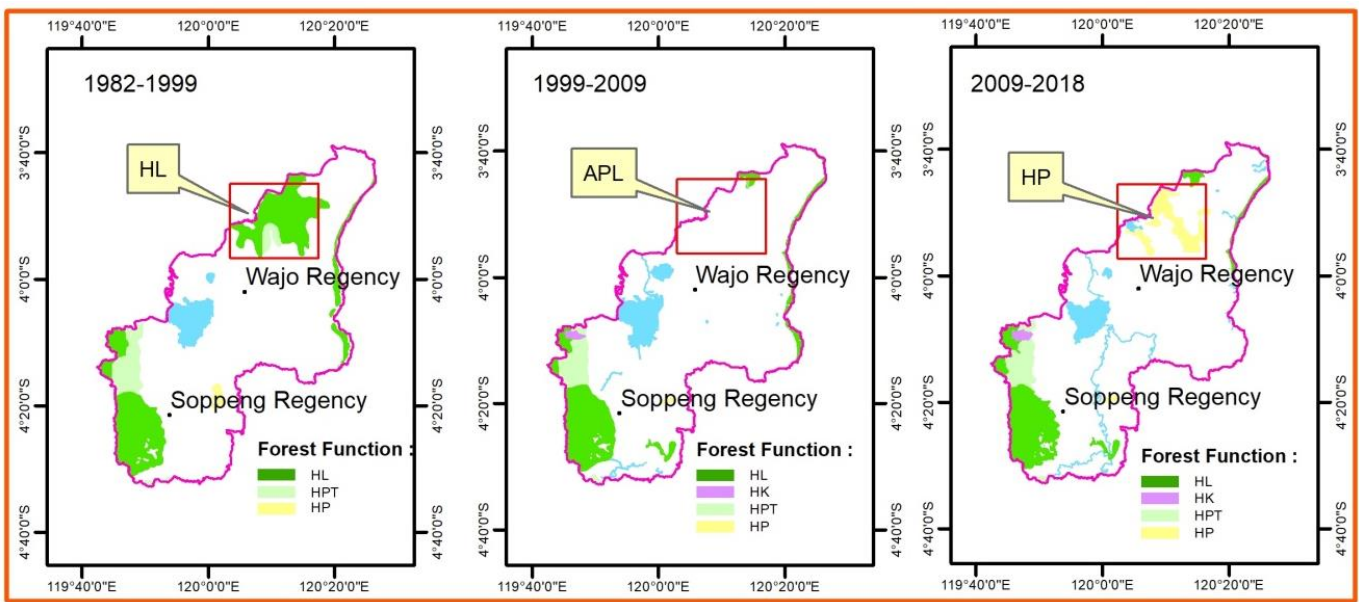


Tajuddin et.al.: Integrated analysis of forest policies and their impacts on landscape and lifescape dynamics: a case study in the Walanae Forest Management Unit, Indonesia

Fig. 3: Change of forest area regarding the function of forests in 1982, 1999 and 2009. For abbreviations see Fig. 1.

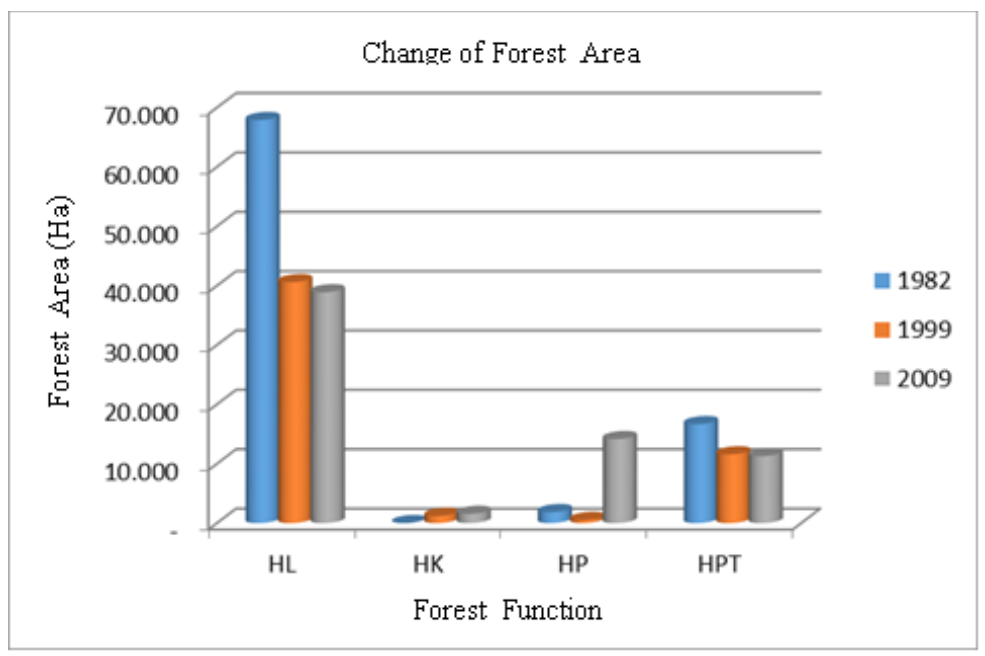

\section{Dynamics of forest utilization policies}

- Reforestation: 1988-2017

The dynamics of forest utilization policies in KPH Walanae working area after approving TGHK in 1982 began with the reforestation policy within the forest area. The reforestation activity aims to restore the forest and its forest function. Based on BPS South Sulawesi province data and BPDAS and HL Jeneberang, the realization of reforestation since 1988 to 2017 in KPH Walanae reached 14,174 ha (Fig. 4). Several types of trees, such as teak, pine, candlenut, eucalyptus, gmelina, jabon, and sengon, were planted for this reforestation.

- Industrial Forest Plantation (HTI) management of PT. Riyani Hutani Sipatuo: 1989-1995

HTI PT. Riyani (later collaborated with PT. Inhutani and renamed the company to PT. Riyani Hutani Sipatuo) has been operating since 1989. However, the HTI working area overlapped with the right of cultivation (HGU) of PT. Bina Mulya Ternak (cattle husbandry) that has been operating since 1972 and community land (settlement and agriculture land/ranch), which has been managed by the community prior to the forest area designation. The land use overlapping case was solved in court, and PT. Bina Mulya Ternak won the case. Therefore, HTI PT. Riyani Hutani Sipatuo has been shut down since 1995.

- Social forestry policies: 1995-present

Although social forestry regulations have been implemented since 1995, the permit request in the KPH Walanae area for a social forestry scheme has just been initiated in 2008 with the issuance of the HTR area allocation in Soppeng district. The follow-up of this allocation is the issuance of HTR in Sering Village (2010). The social forestry scheme permits that were issued after are permits of HKm in Pesse Village and HTR and HKm permits in Patampanua Village in 2013 and 2017, respectively.

In Wajo district, the area allocation for HTR development was issued in 2010 and 2015 for the HKm. However, this allocation could not be maintained until permit issuance given community conflict. In 2016, a partnership with the community (KTH Sipakatau) in KPHP Awota was initiated with the aid from APBN and APBD to develop jabon and natural silk in Minangatellue Village with a total area of 25 ha. 
- Management of KPH: 2013-present

In 2013, the Ministry of Forestry established KPHP Awota in Wajo district, followed by the establishment of UPTD KPHP Awota by regulating the head of Wajo district in 2014. However, the KPHP institution only operated for 3 years. Since 2017, the institution was changed to KPH Walanae, which included UPTD province in the working area located in Soppeng and Wajo districts. This change was the implication of Law number 23 in 2014 on the local government, which relocated the authority of forest sectors from the district to the province.

\section{Fig. 4: Realization of reforestation activities per year}

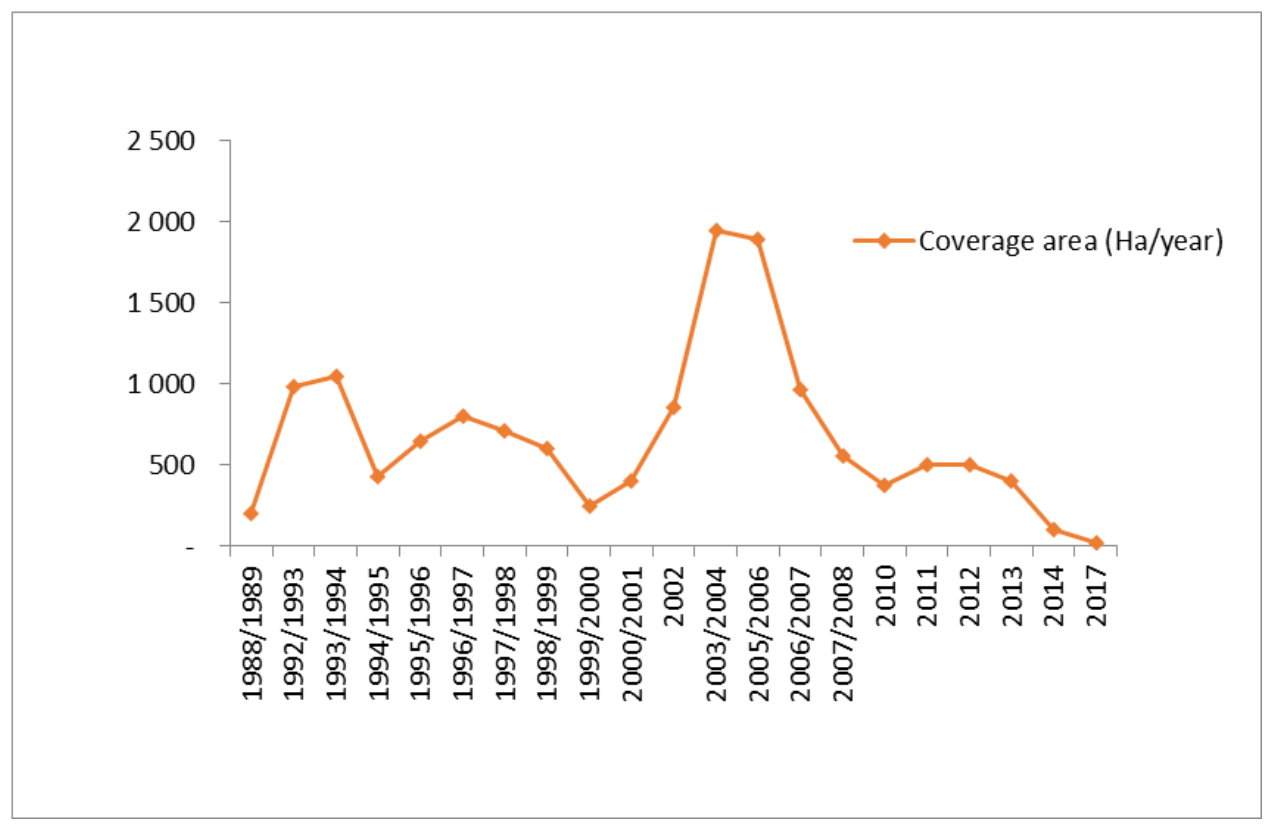

\section{Landscape dynamics}

Analysis of LULCC

A significant change was observed in 1990-2000 (Fig. 5), where the primary forest (Hp) decreased from 26,433 ha (1990) to 2,087 ha (2000). Moreover, shrub (B) decreased considerably from 33,129 ha (1990) to 4,334 ha (2000) (Table 1). The decline of Hp and B in 2000 occurred along with the increase in secondary dry land forest/logged over area (Hs) and dry land agriculture mix shrubs (Pc), where Hs increased from 257 ha (1990) to 24,457 ha (2000), whereas Pc increased from 628 ha (1990) to 29.803 ha (2000). These changes showed a change pattern of Hp to Hs and B to Pc. The dynamics of land covered in 2009 and 2016 showed insignificant change. However, Hp and Hs continuously declined with the increase in B and Pc. 
Fig. 5: LULCC maps for 5 main land cover classes. For abbreviations see Table 1.

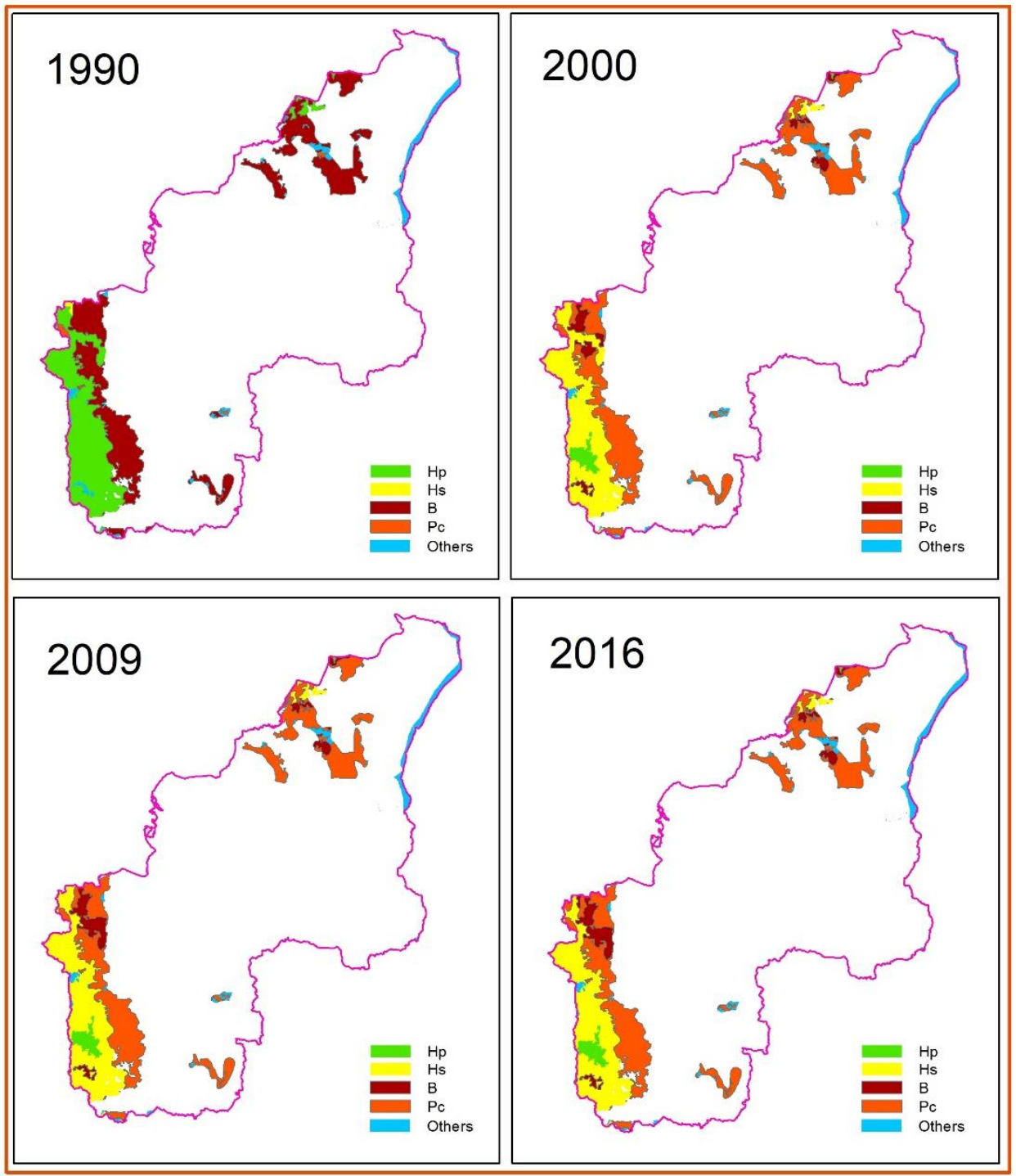

Table 1: Land use and land cover change (in hectares) in KPH Walanae working area 1990-2016

\begin{tabular}{|l|c|c|c|c|}
\hline \multicolumn{2}{|c|}{ Land cover } & \multicolumn{4}{|c|}{ Year } \\
\cline { 2 - 5 } & 1990 & 2000 & 2009 & 2016 \\
\hline Primary forest (Hp) & 26,433 & 2,087 & 2,066 & 2,066 \\
\hline Secondary forest (Hs) & 257 & 24,457 & 23,164 & 22,724 \\
\hline Shrubs (B) & 33,129 & 4,334 & 5,332 & 5,485 \\
\hline Dry land agriculture mix shrubs (Pc) & 628 & 29,803 & 30,118 & 30,394 \\
\hline Others & 5,342 & 5,104 & 5,104 & 5,113 \\
\hline
\end{tabular}


Based on the LULCC analysis, the land cover change in KPH Walanae followed a similar pattern, that is, primary forest $\rightarrow$ secondary forest $\rightarrow$ shrub $\rightarrow$ dry land agriculture mix shrubs. Most of this land cover change was due to land conversion to agriculture executed by the community by shifting their cultivation system. In the first step, the forest area was cut and burnt to clear the area, and then the area was planted with palawija crops and candlenut. After 3 years, when the candlenut had grown and had produced fruits, the community left the area and opened a new land.

\section{Analysis of landscape structure (landscape metrics)}

The result of landscape structure analysis is presented in Fig. 6 and Table 2. The class area analysis was presented in the abovementioned land cover change analysis. In 1990, the land cover of KPH Walanae was dominated by shrub (B) and primary forest (Hp). PLAND results for B and HP were 50.36 and 40.18, correspondingly. However, since 2000, the land cover type, which was dominated by Pc (PLAND: 45.30 from 0.95 in 1990) and Hs (PLAND: 37.18 from 0.39 in 1990), had changed drastically. The result was supported by the TE, which showed a similar trend when the TE decreased for B and HP, and the TE had significantly increased for Pc and HS until 2016.

Fig. 6: Landscape metrics graph of study area. For abbreviations see Table 2.
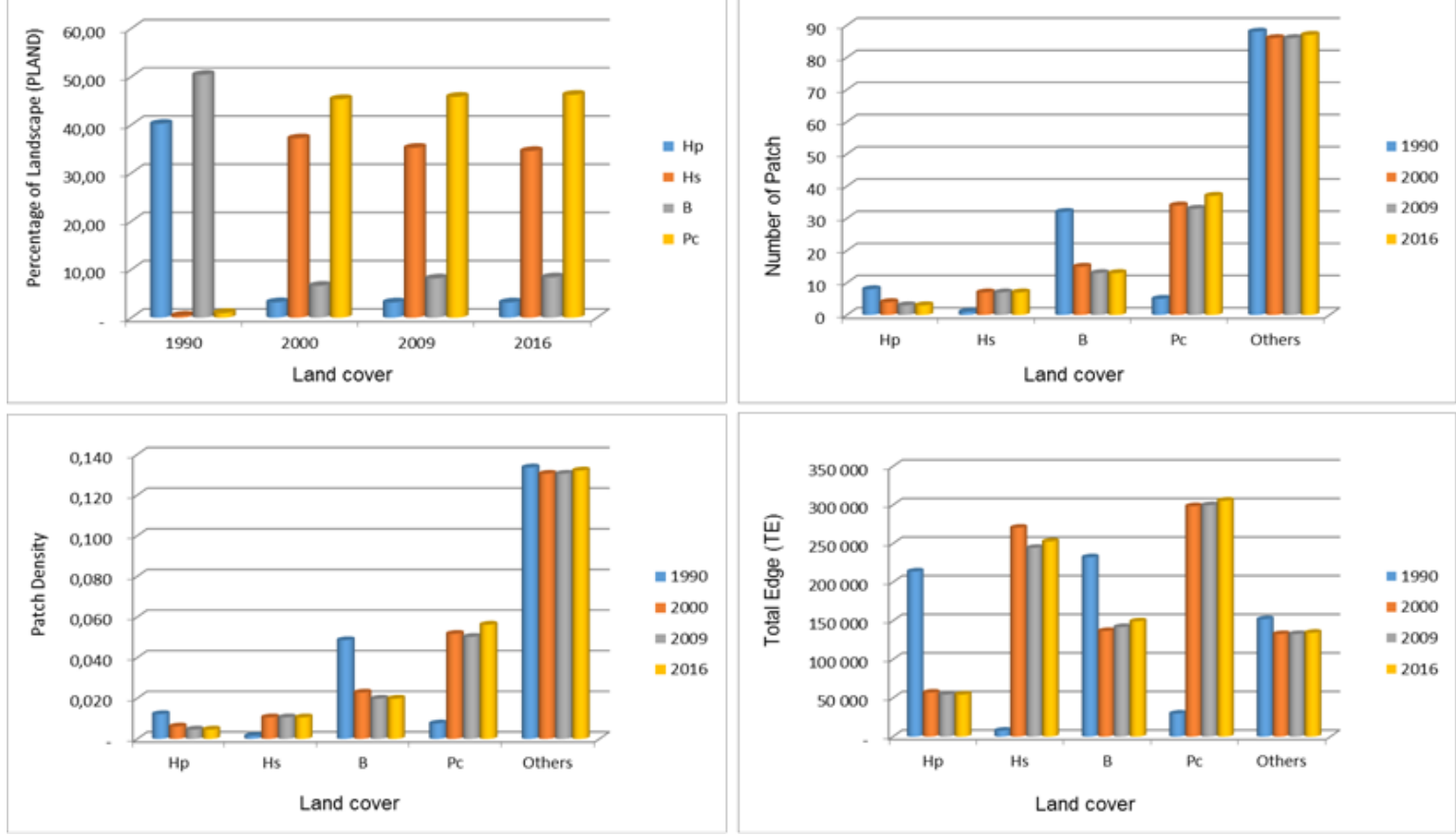
Tajuddin et.al.: Integrated analysis of forest policies and their impacts on landscape and lifescape dynamics: a case study in the Walanae Forest Management Unit, Indonesia

Table 2: Landscape metrics for chosen index in class level

\begin{tabular}{|l|c|c|c|c|c|c|c|c|}
\hline \multirow{2}{*}{ Class } & \multicolumn{3}{|c|}{$\begin{array}{c}\text { Percentage of Landscape (PLAND) } \\
\text { (Percent) }\end{array}$} & \multicolumn{5}{c|}{ Number of Patch (NP) } \\
\cline { 2 - 10 } & 1990 & 2000 & 2009 & 2016 & 1990 & 2000 & 2009 & 2016 \\
\hline Primary forest (Hp) & 40.18 & 3.17 & 3.14 & 3.14 & 8 & 4 & 3 & 3 \\
\hline Secondary forest (Hs) & 0.39 & 37.18 & 35.21 & 34.54 & 1 & 7 & 7 & 7 \\
\hline Shrubs (B) & 50.36 & 6.59 & 8.11 & 8.34 & 32 & 15 & 13 & 13 \\
\hline $\begin{array}{l}\text { Dry land agriculture mix } \\
\text { shrubs (Pc) }\end{array}$ & 0.95 & 45.30 & 45.78 & 46.20 & 5 & 34 & 33 & 37 \\
\hline Others & 8.12 & 7.76 & 7.76 & 7.77 & 88 & 86 & 86 & 87 \\
\hline
\end{tabular}

\begin{tabular}{|l|c|c|c|c|c|c|c|c|}
\hline \multirow{2}{*}{ Class } & \multicolumn{3}{|c|}{$\begin{array}{c}\text { Patch Density (PD) } \\
\text { (Number per 100 hectares) }\end{array}$} & \multicolumn{4}{c|}{$\begin{array}{c}\text { Total Edge (TE) } \\
\text { (Meters) }\end{array}$} \\
\cline { 2 - 10 } & 1990 & 2000 & 2009 & 2016 & 1990 & 2000 & 2009 & 2016 \\
\hline Primary forest (Hp) & 0.012 & 0.006 & 0.005 & 0.005 & 213,900 & 57,060 & 54,540 & 54,540 \\
\hline Secondary forest (Hs) & 0.002 & 0.011 & 0.011 & 0.011 & 7,710 & 270,630 & 244,470 & 252,750 \\
\hline Shrubs (B) & 0.049 & 0.023 & 0.020 & 0.020 & 232,260 & 136,770 & 141,900 & 149,310 \\
\hline $\begin{array}{l}\text { Dry land agriculture mix } \\
\text { shrubs (Pc) }\end{array}$ & 0.008 & 0.052 & 0.050 & 0.056 & 29,820 & 298,440 & 299,730 & 305,580 \\
\hline Others & 0.134 & 0.131 & 0.131 & 0.132 & 152,130 & 132,840 & 132,840 & 134,520 \\
\hline
\end{tabular}

The total patch increased from 1990 to 2000 . The total patches for the four coverage areas were 134 (1990), 146 (2000), 142 (2009), and 147 (2016). The total patch and patch density for Pc and Hs class increased from 1990 to 2000. By contrast, the NP and PD of Hp and B declined during these periods. The forest area in KPH Walanae had experienced continuous land degradation and fragmentation. Forest areas, especially primary forests, had been declining, whereas agricultural land and secondary forest increased. The LPI declined from 38.46 (1990), 35.55 (2000), 33.59 (2016), and 32.92 (2016), thus showing an increase in forest fragmentation. The research result from Adepoju and Salami (2017) indicated a similar trend, where high fragmentation occurred in 1991 and 2000 and caused significant landscape variabilities.

\section{Lifescape dynamics}

Livelihood

The main livelihood/occupation of the communities in the study area showed that agricultural activity remains the major livelihood. In 1990, the number of farmers in Soppeng district was approximately $59 \%$ and $60 \%$ in Wajo district. This number decreased in 2015 to $44.7 \%$ in Soppeng district and $46.7 \%$ in Wajo district (BPS-Statistics of Soppeng Regency, 2017; BPS-Statistics of Wajo Regency, 2017). Specifically, our research sample location showed that several community groups have different livelihood patterns. Communities that live within the forest area are mostly farmers who rely on the forest and palawija plant and in collecting candlenut, honey, and palm sugar (aren). By contrast, the community living outside the forest area comprised paddy farmers and cattle raisers. 


\section{Crop/forest production}

Crop production from three commodities showed an increasing trend for cacao and maize, whereas candlenut production showed an inconsistent result (Fig. 7). The three commodities are products that are closely related to the community living within and surrounding the forest.

\section{Fig. 7: Crop and forest production in two districts}

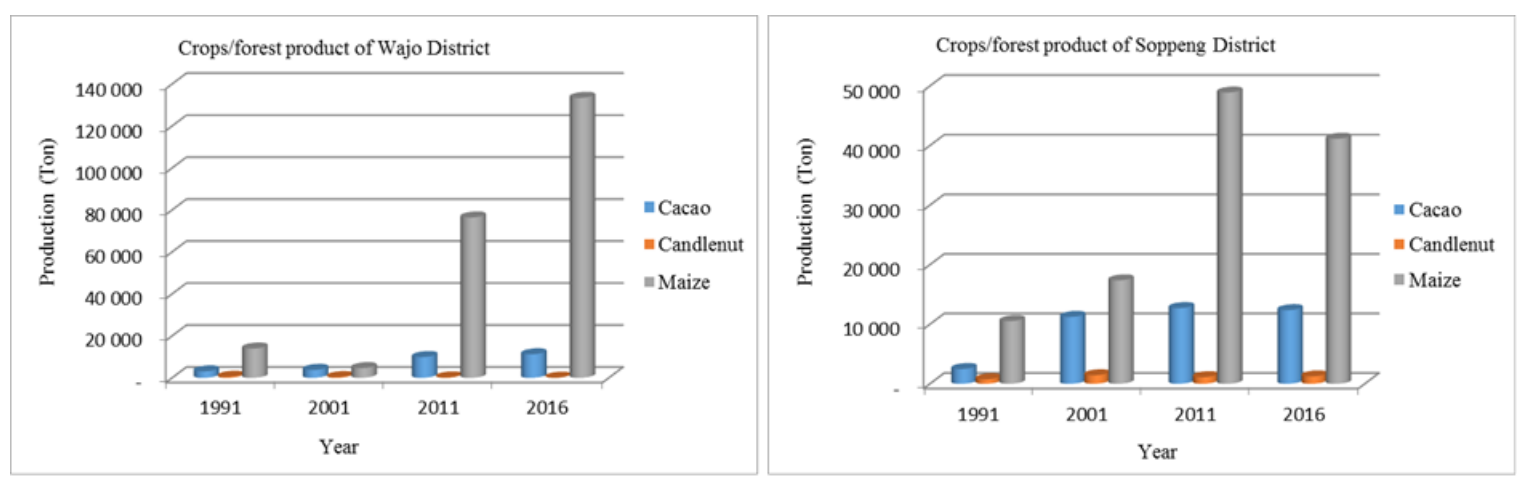

\section{Land tenure}

Land cover change from the forest area to agriculture land and settlement affected the increase in agriculture land and the community's land tenure in the study area. If we analyze the land tenure per household, then the community that lives within and surrounding the forest area of KPH Walanae owned more than 1 ha land with the largest proportion of 1-2 ha (Hasanuddin, 2017). The community who had a social forest scheme owned land for more than 3-9 ha per household.

\section{Income}

The dynamics of the community's income showed an increase from 1995 to 2016 (Fig. 8). In 1995, the GRDP per capita in Soppeng district was 1.14 million rupiah and reached 35.07 million rupiah in 2016. In the Wajo district, the GRDP per capita was 1.48 million rupiah in 1995 and reached 41.93 million rupiah in 2016. The role of agricultural sector on the GRDP decreased.

Furthermore, using a per capita expenditure approach for the community income analysis, we found that the community's income in each research site accounted for 5.42 million rupiah per capita per year in Soppeng district (BPS-Statistics of Soppeng Regency, 2017a) and 9.4 million rupiah for Wajo district (BPS-Statistics of Wajo Regency, 2017a). The income per household with four people within the household is 21.68 million rupiah (Soppeng district) and 37.6 million rupiah (Wajo district). The income value was higher than the research conducted by Hasanuddin (2017) in Wajo district, in which the estimated income for community living within and surrounding forest area was 16,638 million rupiah. 
Tajuddin et.al.: Integrated analysis of forest policies and their impacts on landscape and lifescape dynamics: a case study in the Walanae Forest Management Unit, Indonesia

Fig. 8: GRDP per capita and the role of agricultural sector on GRDP in two districts

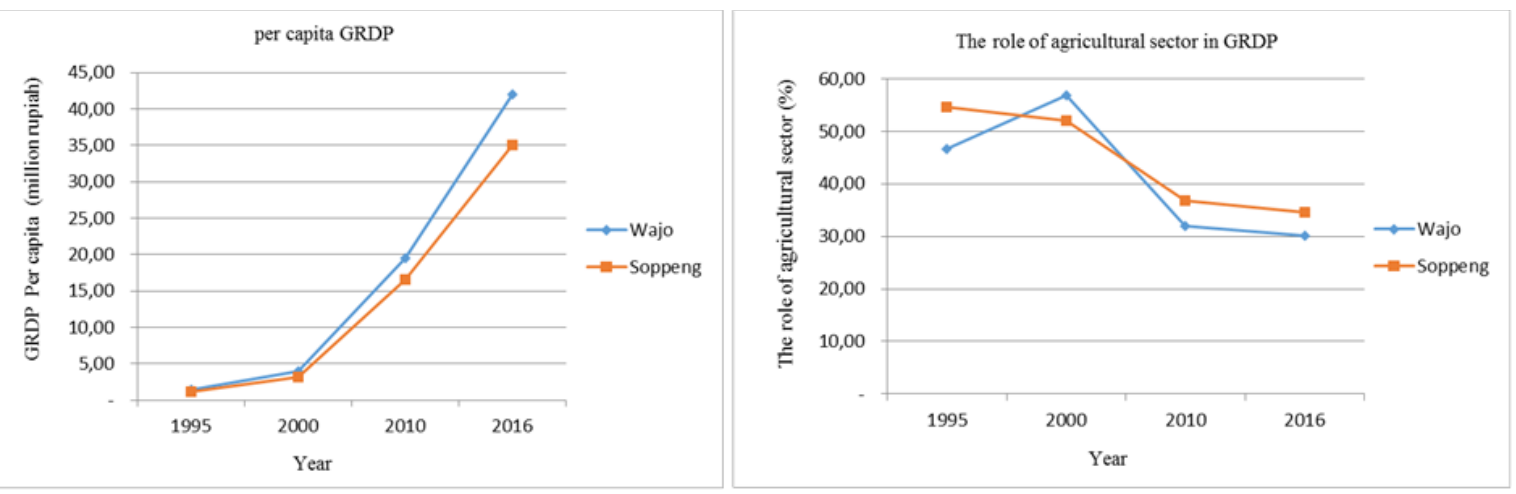

\section{DISCUSSION}

\section{Impact of forest policies on landscape dynamics}

Forest policies on forest land designation has changed forest landscape. The area designated as a forest area is small or not even a forested area (Contreras-Hermosilla \& Fay, 2006). This condition has occurred in the KPH Walanae working area. The forest land designation in 1982 has caused conflict and overlapping land use with HGU permit, settlement, and community plantations. Conflict and unclear land tenure and management of the state forest are considered the causes of deforestation (Muttaqin, 2013). Therefore, forest land designation must consider field condition and involve all relevant stakeholders (Antoko et al, 2008) for an accurate forest land designation (Fay et al., 2000, Fisher et al., 2018).

Forest policies do not ensure forest sustainability. The analysis result on landscape structure and composition shows that the forest area within KPH Walanae is continuously experiencing degradation and fragmentation. In particular, from 1990 to 2000, primary forest and shrubs have declined, whereas agricultural land and secondary forest have increased. This phenomenon is supported by an analysis result on landscape metrics. The main process of land cover change in KPH Walanae due to shifting cultivation system follows the following pattern: 1) conversion, 2) cropping, and 3) fallow (Kleinman et al.,1995; Mustard et al., 2004). The change in landscape composition and configuration has caused potential impacts on forest ecology and major threat on biodiversity (Alig et al., 2005; Legaard et al., 2015).

An analysis on the cause of forest degradation from 1990 to 2000 can be observed in forest policies on the HTI management of PT. Riyani Hutani Sipatuo from 1989 to 1995. Although PT. Riyani Hutani Sipatuo has planted several types of acacia, gmelina, and sengon, such trees did not develop well due to many disturbances, such as ungulates, fire, and soil condition (thin soil layer), and many trees were left in open areas. Kartodihardjo and Supriono (2000) concluded that policies on HTI establishment generally may support natural forest destruction.

The absence of the institution at the ground level and the lack of monitoring have caused the encroachment of communities by converting forest area into agricultural lands and subsequently shifting to cultivation. This strategy is supported by the road construction prior to 1990 that reached the forest area (Fig. 1). Furthermore, the transition from centralized to regional autonomy from 1998 to 2003 has increased the deforestation rate considering law 
enforcement uncertainty, which caused the encroachment and occupancy of forest land (Prasetyo et al., 2014). The shifting of the forest area into other land use for agricultural land and settlements is a common phenomenon worldwide (Mekonnen \& Bluffstone, 2007; Antoko et al, 2008; Schulz et al., 2010; Msoffe et al., 2011; Linh et al., 2012; Thies et al., 2014; Adhikari et al., 2015; Dimobe et al., 2017).

Policies on establishing the KPH organization as a mainstream forest management have become an urgent policy that must be implemented (Kartodihardjo et al., 2011; Rizal et al., 2011). The KPH is presented as a construction of forestry block building to resolve specific issues at the field level (Setyarso et al., 2014) and enable conditions to accomplish sustainable forest management (Supratman, 2007). However, until 2018, the forest management performance through the KPH institution, especially in South Sulawesi province, has remained lacking. Several KPH institutions that were approved has undergone changes in the new institution (including KPH Walanae) as the result of Law number 23, which was implemented in 2014. This condition shows that the KPH institution that has been approved faces internal management issues, especially in terms of facilities and limited funding. Sahide et al. (2016) presented the attempts of the central government in regaining its authority in administering and managing the forest (recentralization strategy) through a system called Forest Management Unit (KPH), which is still considered relevant in this condition.

The reforestation program implemented since the 1980s is a forest policy that contributed positively to forest cover. However, field condition shows that several areas are inaccurately labeled as shrubs because the growth includes candlenut vegetation, teak, and eucalyptus trees. The inaccurate interpretation is attributed to the spatial resolution that is $30 \mathrm{~m}$ from the Landsat, thereby making the identification of small objects in the resolution difficult (Mutoko et al., 2014).

\section{Impact of forest policies on lifescape dynamics}

In addition to causing forest landscape change, forest land designation has affected community lifescape conditions. Conflicts and overlapping forest lands with the settlement and community agricultural land have caused uncertainty in land tenure right. For example, the community living within and surrounding the forest is highly dependent on the forest for their main livelihood (Maryudi et al., 2015; Salman, 2016). The field condition shows that the village within the forest area has been present prior to the forest designation in 1982 . Currently, the community still stays and continues to cultivate within the forest area, although the land tenure remains unclear. Fay and Sirait (2004) estimated millions of hectares of community agricultural land comprising various trees, such as fruits, resins, coffee bean, and cocoa; agroforestry is a common practice within the forest area.

Land tenure uncertainty plays an important role in the community in terms of conflict, which at times ends up in rage. This situation frequently occurs across Indonesia where conflicts among communities, governments, concession companies, and agricultural companies are increasing (Kusumanto \& Sirait, 2002; Contreras-Hermosilla \& Fay, 2006). In several cases, forest policies cause the community to suffer due to loss of livelihood (Siburian, 2004; Salman, 2016). Therefore, a social forestry scheme is necessary to solve this issue. The main objective of social forestry is to improve local community livelihood and forest resource condition where the community lives and relies for their living (Gregersen et al., 1989; Ojha et al., 2009; Gelo \& Koch, 2012; Barsimantov \& Navia Antezana, 2012; Schusser, 2013; Pokharel et al., 2014; Schusser et al., 2015; Aheto et al., 2016). However, the policies and funding support on social forestry are unable to improve the performance of social forestry in the field. In general, community forestry still receives many critics (Hajjar 
et al., 2013) and has not been implemented effectively (Cronkleton et al., 2013; Soepijanto et al., 2013; Schusser et al., 2014).

Although forest policies on forest utilization has not provided a significant impact on landscape improvement, such measures have provided economic benefits to the community. The HTI management of PT. Riyani Hutani Sipatuo within their operational period has provided additional income to the surrounding community. The company provides work opportunities for the community, especially for land management, planting, and maintenance of the HTI. The same benefits are given to the community during the reforestation program by the government, in which the community becomes involved in nursery activity, land management, planting, and maintenance.

Forest plantation from the reforestation has been providing ecological and economic benefits for the community. Several parts of the area have been illegally harvested, and other parts of the area are legally maintained for resin tapping and candlenut production. In other sites, the community utilizes the forest for non-timber forest products, such as harvesting for candlenut, pine resin, palm sugar, and honey, as their livelihood. The income per capita per month is estimated to be approximately 0.347 million rupiah; thus, several communities within the KPH Walanae working area are considered living above the poverty level (0.258 million rupiah per month per capita in 2016).

\section{CONCLUSION}

The various forest policies that has been implemented in the KPH Walanae working area since 1982 have influenced the forest composition and cover, but these policies has been insufficiently successful in protecting the natural forest. Forest area designation has affected the overlapping forest area with other land usage and uncertainty of tenure right. The incapability of forestry institution to manage and monitor the forest area has caused occupancy and forest encroachment by the community. Forest management policies in the form of industrial forest plantations are unable to operate efficiently given overlapping permit. The impact from these policies are continuous degradation and deforestation of forest landscape. Based on GIS analysis, the decreased area of forests has resulted in high income for people on one side and large disturbances and forest fragmentation on the other.

The government's efforts in reforestation activities have become a policy that improved landscape and lifescape of the community. The improvement of forest cover and economic function received by the community are the pieces of evidence of the success of reforestation. Furthermore, the policies on establishing KPH and social forest program have not shown maximum results on the landscape and lifescape improvements. Therefore, these policies required support.

\section{AKNOWLEDGMENTS}

We are grateful to the Ministry of Environment and Forestry for funding this research through the Center of Forestry and Environment Education, Training, and Human Resources Development, and all persons who have helped in conducting this research. 


\section{REFERENCES}

Abdullah, A. N. M., Stacey, N., Garnett, S. T., \& Myers, B. (2016). Forest Policy and Economics Economic dependence on mangrove forest resources for livelihoods in the Sundarbans , Bangladesh. Forest Policy and Economics, 64, 15-24. https://doi.org/10.1016/ j.forpol.2015.12.009

Adepoju, K. A., \& Salami, A. T. . (2017). Geospatial Assessment of Forest Fragmentation and Its Implications for Ecological Processes in Tropical Forests. Journal of Landscape Ecology, 10(2), 19-34. https://doi.org/10.1515/jlecol-2017-0002

Adhikari, S., Southworth, J., \& Nagendra, H. (2015). Understanding forest loss and recovery: a spatiotemporal analysis of land change in and around Bannerghatta National Park, India. Journal of Land Use Science, 10(4), 402-424. https://doi.org/10.1080/1747423 X.2014.920425

Aheto, D. W., Kankam, S., Okyere, I., Mensah, E., Osman, A., Jonah, F. E., \& Mensah, J. C. (2016). Community-based mangrove forest management: Implications for local livelihoods and coastal resource conservation along the Volta estuary catchment area of Ghana. Ocean and Coastal Management, 127, 43-54. https://doi.org/10.1016/j.ocecoaman.2016.04.006

Alig, R. J., Lewis, D. J., \& Swenson, J. J. (2005). Changes In Land Use , Forest Fragmentation, And Policy Responses. Urban Rural Interface Conference Proceedings.

Alphan, H., Doygun, H., \& Unlukaplan, Y. I. (2009). Post-classification comparison of land cover using multitemporal Landsat and ASTER imagery: The case of Kahramanmaras, Turkey. Environmental Monitoring and Assessment, 151(1-4), 327-336. https://doi.org/ 10.1007/s10661-008-0274-X

Amoroso, V. B., Roxas, A. T., Lariosa, E. A., Estoista, R. V. B., Canencia, O. P., Mero, D. C., Cambel, T. L. (2004). Participatory Rural Appraisal in the Lowland Ecosystem of Mt . Malindang , Misamis Occidental, Philippines. Biodiversity Research Programme for Development in Mindanao.

Antoko, B. S., Sanudin, \& Sukmana, A. (2008). Perubahan Fungsi Hutan di Kabupaten Asahan, Sumatera Utara. Info Hutan, 5, 307-316.

Aravindakshan, S. (2011). Evolution of Forest Policies in India and the emergence of Village Forest Councils as rural institutions : A case study on Kerala in India. International Journal of Humanities and Social Science, 1(6), 56-62.

Avanzini, M., Bussolon, S., Caporusso, L., Gios, G., \& Goio, I. (2016). Landscape conservation: The perspectives of experts and other stakeholders. Journal of Landscape Ecology(Czech Republic), 9(2), 5-28. https://doi.org/10.1515/jlecol-2016-0006

Barsimantov, J., \& Navia Antezana, J. (2012). Forest cover change and land tenure change in Mexico's avocado region: Is community forestry related to reduced deforestation for high value crops. Applied Geography, 32(2), 844-853. https://doi.org/10.1016/ j.apgeog.2011.09.001

BPS-Statistics of Soppeng Regency. (2017a). Indikator Kesejahteraan Rakyat Kabupaten Soppeng Tahun 2016. Watansoppeng.

BPS-Statistics of Soppeng Regency. (2017b). Soppeng Regency in Figures 2017. Watansoppeng.

BPS-Statistics of Wajo Regency. (2017a). Indikator Kesejahteraan Rakyat Kabupaten Wajo Tahun 2016. Sengkang.

BPS-Statistics of Wajo Regency. (2017b). Wajo Regency in Figures 2017. Sengkang. 
Chavez, A. B. (2014). Landscape dynamics of Amazonian deforestation between 1986 and 2007 in southeastern Peru: policy drivers and road implications. Journal of Land Use Science, 9(4), 414-437. https://doi.org/10.1080/1747423X.2013.807310

Contreras-Hermosilla, A., \& Fay, C. (2006). Memperkokoh Pengelolaan Hutan Indonesia Melalui Pembaruan Sistem Penguasaan Tanah: Permasalahan dan Kerangka Tindakan. Bogor: World Agroforestry Centre. Retrieved from http://www.rightsandresources. org/documents/files/doc_1541.PDF

Cronkleton, P., Larson, A. M., Feintrenie, L., Garcia, C., \& Levang, P. (2013). Reframing Community Forestry to Manage the Forest-Farm Interface. Small-Scale Forestry, 12(1), 513. https://doi.org/10.1007/s11842-012-9229-8

Dhakal, B., Bigsby, H., \& Cullen, R. (2012). Socioeconomic Impacts of Public Forest Policies on Heterogeneous Agricultural Households. Environmental and Resource Economics, 53(1), 73-95. https://doi.org/10.1007/s10640-012-9548-4

Dimobe, K., Goetze, D., Ouédraogo, A., Forkuor, G., Wala, K., Porembski, S., \& Thiombiano, A. (2017). Spatio-Temporal Dynamics in Land Use and Habitat Fragmentation within a Protected Area Dedicated to Tourism in a Sudanian Savanna of West Africa. Journal of Landscape Ecology(Czech Republic), 10(1), 75-95. https://doi.org/10.1515 /jlecol-2017-0011

Dotzauer, H. (1993). The Political and Socio-Economic Factors Causing Forest Degradation in The Dominican Republic. Rural Development Forestry Network Paper 16d. https://doi.org/10.1177/030913339802200306

Fay, C., \& Sirait, M. (2004). Kerangka Hukum Negara dalam Mengatur Agraria dan Kehutanan Indonesia: Mempertanyakan Sistem Ganda Kewenangan atas Penguasaan Tanah. Paper Dipresentasikan Dalam The International Conference on Land Tenure, Jakarta, 11-13 October 2004.

Fay, C., Sirait, M., \& Kusworo, A. (2000). Getting the Boundaries Right: Indonesia's Urgent Need to Redefine its Forest Estate. Southeast Asia Policy Research Working Paper, (25), 23.

Fisher, M. R., Moeliono, M., Mulyana, A., Yuliani, E. L., Adriadi, A., Judda, J., \& Sahide, M. A. K. (2018). Assessing the new social forestry project in Indonesia: recognition, livelihood and conservation?. International Forestry Review, 20(3), 346-361. https://doi.org/10.1505/146554818824063014

Fitzsimons, P. J., \& Cherry, D. (2008). Placing People at the Centre of Landscape Assessment in : C. Pettit, W. Cartwright, I. Bishop, K. Lowell, D. Pullar and D. Duncan Eds. Landscape Analysis and Visualisation_Spatial Models for Natural Resource Management and Planning. Lecture Notes in Geoinformation and Cartography. https://doi.org/10.1007 1978-3-540-88183-4

Garcia, A. S., \& Ballester, M. V. R. (2016). Land cover and land use changes in a Brazilian Cerrado landscape: drivers, processes, and patterns. Journal of Land Use Science, 11(5), 538-559. https://doi.org/10.1080/1747423X.2016.1182221

Geist, H. J., \& Lambin, E. F. (2002). Proximate Causes and Underlying Driving Forces of Tropical Deforestation. BioScience, 52(2), 143. https://doi.org/10.1641/00063568(2002)052[0143:PCAUDF]2.0.CO;2

Geist, H., McConnell, W., Lambin, E. F., Moran, E., Alves, D., \& Rudel, T. (2006). Causes and Trajectories of Land-Use/Cover Change. In: E. F. Lambin \& H. J. Geist (Eds) Land-Use and Land Cover Change, Pp. 41-70 (Berlin: Springer). Gennaio,. https://doi.org/10.1016 
/B978-0-7020-2793-2.00003-7

Gelo, D., \& Koch, S. F. (2012). Does one size fit all? Heterogeneity in the valuation of community forestry programs. Ecological Economics, 74, 85-94. https://doi.org/10.1016 /j.ecolecon.2011.11.010

Gibbes, C., Havlick, D. G., \& Robb, J. R. (2017). Land use and land cover in a transitioning militarized landscape. Journal of Land Use Science, 12(2-3), 182-196. https://doi.org/ 10.1080/1747423X.2017.1313325

Grebner, D., Bettinger, P., \& Siry, J. P. (2013). Forest Policies and External Pressures, 359383. https://doi.org/10.1016/B978-0-12-386901-2.00015-4.

Gregersen, H., Draper, S., \& (eds)., D. E. (1989). People and Trees: The Role of Social Forestly in Sustainable Development, . Washington, D.C.: The World Bank.

Günter S, Köthke M, Schröder J-M, F. R. (2015). LaForeT Landscape Forestry in the Tropics: Towards policy approaches for improving livelihoods, sustainable forest management and conservation. Concept Note. Hamburg.

Hajjar, R., Kozak, R. A., El-Lakany, H., \& Innes, J. L. (2013). Community forests for forest communities: Integrating community-defined goals and practices in the design of forestry initiatives. Land Use Policy, 34, 158-167. https://doi.org/10.1016/j.landusepol.2013.03.002

Hargrove, W. L., Garrity, D. P., Rhoades, R. E., \& Neely, C. L. (2000). A landscape/lifescape approach to sus- tainability in the tropics: the experience of the SANREM CRSP at three sites. In: R. Lal, Ed. Integrated Watershed Management in the Global Ecosystem., Boca Raton, Florida: CRC Press, 209-222.

Hasanuddin. (2017). Model Kolaborasi Pengelolaan Blok Pemberdayaan Kesatuan Pengelolaan Hutan Produksi Awota Kabupaten Wajo Provinsi Sulawesi Selatan. Disertasi. Program Pascasarjana, Unhiversitas Hasanuddin. (Tidak Dipublikasikan), 67. https://doi.org/10.1590/S1516-18462008000300012

Hersperger, A. M., \& Bürgi, M. (2010). How do policies shape landscapes? Landscape change and its political driving forces in the Limmat Valley, Switzerland 1930-2000. Landscape Research, 35(3), 259-279. https://doi.org/10.1080/01426391003743561

Kartodihardjo, H., Nugroho, B., \& Putro, H. R. (2011). Pembangunan Kesatuan Pengelolaan Hutan (KPH) - Konsep, Peraturan Perundangan dan Implementasi. Direktorat Wilayah Pengelolaan dan Penyiapan Areal Pemanfaatan Kawasan Hutan, Direktur Jenderal Planologi Kehutanan Diterbitkan.

Kartodihardjo, H., \& Supriono, A. (2000). Dampak Pembangunan Sektoral terhadap Konversi dan Degradasi Hutan Alam: Kasus Pembangunan HTI dan Perkebunan di Indonesia. Center for International Foresty Research, 26(I), 1-14.

Käyhkö, N., Fagerholm, N., \& J. Mzee, A. (2015). Local farmers' place-based forest benefits and government interventions behind land and forest cover transitions in Zanzibar, Tanzania. Journal of Land Use Science, 10(2), 150-173. https://doi.org/10.1080/1747423 X.2013.858784

Kleinman, P. J. A., Pimentel, D., \& Bryant, R. B. (1995). The ecological sustainability of slash-and-burn agriculture. Agriculture, Ecosystems and Environment, 52(2-3), 235-249. https://doi.org/10.1016/0167-8809(94)00531-I

Kusumanto, Y., \& Sirait, M. T. (2002). Community Participation in Forest Resource Management in Indonesia: Policies, Practices, Constraints and Opportunities. Southeast Asia Policy Research Working Paper No. 28. ICRAF, (28). 
Tajuddin et.al.: Integrated analysis of forest policies and their impacts on landscape and lifescape dynamics: a case study in the Walanae Forest Management Unit, Indonesia

Legaard, K. R., Sader, S. A., \& Simons-Legaard, E. M. (2015). Evaluating the impact of abrupt changes in forest policy and management practices on landscape dynamics: Analysis of a landsat image time series in the Atlantic Northern forest. PLOS ONE, 10(6), 1-24. https://doi.org/10.1371/journal.pone.0130428

Linh, N. H. K., Erasmi, S., \& Kappas, M. (2012). Quantifying Land Use / Cover Change and Landscape Fragmentation in Danang City , Vietnam: 1979-2009. XXII ISPRS Congress, XXXIX(September), 501-506.

Loxton, E., Schirmer, J., \& Kanowski, P. (2014). Social impacts of forest policy changes in Western Australia on members of the natural forest industry: Implications for policy goals and decision-making processes. Forestry, 87(3), 363-376. https://doi.org/10.1093/ forestry/cpu011

Maryani, R., Suka, A. P., Alvya, I., \& Saparis. (2014). Sintesis Riset Integratif Manajemen Lanskap Hutan Berbasis DAS.

Maryudi, A., Citraningtyas, E. R., Purwanto, R. H., Sadono, R., Suryanto, P., Riyanto, S., \& Siswoko, B. D. (2015). The emerging power of peasant farmers in the tenurial conflicts over the uses of state forestland in Central Java, Indonesia. Forest Policy and Economics, 67(OCTOBER), 70-75. https://doi.org/10.1016/j.forpol.2015.09.005

McGarigal, K., \& Marks, B. J. (1995). FRAGSTAT: Spatial pattern analysis program for quantifying landscape structure. Gen. Tech. Rep. PNW-GTR-351. Portland, OR: U.S. Department of Agriculture, Forest Service, Pacific Northwest Research Station., 122 pages. https://doi.org/10.1061/(ASCE)0733-9437(2005)131:1(94) CE

Mekonnen, A., \& Bluffstone, R. (2007). Policies to increase forest cover in Ethiopia: lessons from economics and international experience. Proceedings of a Policy Workshop : Policies to Increase Forest Cover in Ethiopia, 23-68.

Menon, A., Hinnewinkel, C., Guillerme, S., Laval, M., \& Garcia, C. (2008). ' Forests ', Agrarian Landscapes and Public Policies in the Central Western Ghats of South India. Paper Presented at the 12th Biennial Conference of the International Association for the Study of the Commons (IASC) Governing Shared Resources: Connecting Local Experience to Global Challenges Held at the University of Gloucestershire, U.K., 1-22.

Msoffe, F. U., Said, M. Y., Ogutu, J. O., Kifugo, S. C., De, J., Gardingen, P. Van, \& Reid, R. S. (2011). Spatial correlates of land-use changes in the Maasai- Steppe of Tanzania: Implications for conservation and environmental planning. International Journal of Biodiversity and Conservation, 3(7), 280-290.

Mustard, J. F., Defries, R. S., Fisher, T., \& Moran, E. (2004). Land-Use and Land-Cover Change Pathways and Impacts in Gutman et al (eds) Land Change Science: Observing, Monitoring, and Understanding Trajectories of Change on Earth's Surface Kluwier Netherlands. https://doi.org/10.1007/978-1-4020-2562-4_24

Mutoko, M. C., Hein, L., \& Bartholomeus, H. (2014). Integrated analysis of land use changes and their impacts on agrarian livelihoods in the western highlands of Kenya. AGRICULTURAL SYSTEMS, 128, 1-12. https://doi.org/10.1016/j.agsy.2014.04.001

Muttaqin, M. Z. (2013). Pengelolaan Lahan dan Hutan di Indonesia: Akses Masyarakat Lokal ke Sumberdaya Hutan dan Pengaruhnya pada Pembayaran Jasa Lingkungan dalam M.Z. Muttaqin dan Subarudi (Eds). Pengelolaan Kawasan Hutan dan Lahan dan Pengaruhnya bagi Pelaksanaan REDD+ di Indo. Pusat Penelitian dan Pengembangan Perubahan Iklim dan Kebijakan, Badan Penelitian dan Pengembangan Kehutanan. 
OECD. (2010). Regulatory Policy and the Road to Sustainable Growth.

Ojha, H. R., Cameron, J., \& Kumar, C. (2009). Forest Policy and Economics Deliberation or symbolic violence? The governance of community forestry in Nepal. Forest Policy and Economics, 11(5-6), 365-374. https://doi.org/10.1016/j.forpol.2008.11.003

Pokharel, R. K., Neupane, P. R., Tiwari, K. R., \& Köhl, M. (2014). Assessing the sustainability in community based forestry: A case from Nepal. Forest Policy and Economics, 58(June 1992), 75-84. https://doi.org/10.1016/j.forpol.2014.11.006

Prasetyo, L. B., Damayanti, E. K., Moy, M. S., Purnama, S. I. S., Sumantri, H., Haasler, B., \& Zulfikhar. (2014). Kerangka Kerja Penyusunan Indikator dan Parameter Keanekaragaman Hayati untuk Sistem Pemantauan Multiguna di Sumatera Selatan. Biodiversity and Climate Change (BIOCLIME) Project. Deutsche Gesellschaft Für Internationale Zusammenarbeit (GIZ). Palembang Perpustakaan, 83. Retrieved from http://bioclime.org/publications/ Laporan-Akhir-Framework-Kriteria-dan-Indikator-15-Jan-2015_Ind_Bioclime-cover-Redu ced.pdf

Rizal, A., Dewi, I. N., \& Kusumedi, P. (2011). Kajian Strategi Implementasi Kesatuan Pengelolaan Hutan ( KPH ): Studi Kasus di Kabupaten Tana Toraja. Jurnal Analisis Kebijakan Kehutanan, 8(2), 167-188.

Sahide, M. A. ., Supratman, S., Maryudi, A., Kim, Y. ., \& Giessen, L. (2016). Decentralisation policy as recentralisation strategy: forest management units and community forestry in Indonesia. International Forestry Review, 18(1), 78-95. https://doi.org/10.1505 /146554816818206168.

Salman, D. (2016). Sosiologi Desa: Revolusi Senyap dan Tarian Kompleksitas (Cet. 2). Ininnawa.

Schulz, J. J., Cayuela, L., Echeverria, C., Salas, J., \& Rey Benayas, J. M. (2010). Monitoring land cover change of the dryland forest landscape of Central Chile (1975-2008). Applied Geography, 30(3), 436-447. https://doi.org/10.1016/j.apgeog.2009.12.003

Schusser, C. (2013). Who determines biodiversity? An analysis of actors' power and interests in community forestry in Namibia. Forest Policy and Economics, 36, 42-51. https://doi.org/10.1016/j.forpol.2012.06.005

Schusser, C., Krott, M., Movuh, M. C. Y., Logmani, J., Devkota, R. R., Maryudi, A., \& Salla, M. (2014). Comparing community forestry actors in Cameroon, Indonesia, Namibia, Nepal and Germany. Forest Policy and Economics, 1-7. https://doi.org/10.1016/j.forpol .2016.03.001

Schusser, C., Krott, M., Yufanyi Movuh, M. C., Logmani, J., Devkota, R. R., Maryudi, A., ... Bach, N. D. (2015). Powerful stakeholders as drivers of community forestry - Results of an international study. Forest Policy and Economics, 58, 92-101. https://doi.org/10.1016/ j.forpol.2015.05.011

Setyarso, A., Djajono, A., Nugroho, B., Wulandari, C., Suwarno, E., Kartodihardjo, H., \& Sardjono, M. A. (2014). Strategi Pengembangan KPH dan Perubahan Struktur Kehutanan Indonesia. Direktorat Jenderal Planologi Kehutanan.

Sewnet, A. (2015). Land use/cover change at Infraz Watershed, Northwestren Ethiopia. Journal of Landscape Ecology(Czech Republic), 8(1), 69-83. https://doi.org/10.1515/ jlecol-2015-0005

Shuyu, X., Chunqian, J., Dahong, Z., Meiyan, Z., Qing, Q., \& Shuo, W. (2017). Forestland-cover changes in China's tropical area: Historical patterns, implications, and policy options - a case study from Xishuangbanna. Journal of Sustainable Forestry, 36(1), 
18-31. https://doi.org/10.1080/10549811.2016.1236280

Siburian, R. (2004). Kebijakan Kehutanan Dan Akibatnya Bagi Masyarakat Lokal. Jurnal Masyarakat Dan Budaya, VI(1), 121-136.

Soepijanto, B., Zauhar, S., Haryono, B. S., \& Soeaidy, S. (2013). Model of Effective Community Empowerment Policy of Forestry Partnership to Forest Community in Mesuji-Lampung, 17(1), 7-14.

Southworth, J., Nagendra, H., \& Cassidy, L. (2012). Forest transition pathways in Asia studies from Nepal, India, Thailand, and Cambodia. Journal of Land Use Science, 7(1), 5165. https://doi.org/10.1080/1747423X.2010.520342

Spies, T. A., Johnson, K. N., Burnett, K. M., Ohmann, J. L., McComb, B. C., Reeves, G. H., ... Garber-Yonts, B. (2007). Cumulative ecological and socioeconomic effects of forest policies in coastal Oregon. Ecological Applications, 17(1), 5-17. https://doi.org/10.1890 /1051-0761(2007)017[0005:CEASEO]2.0.CO;2

Supratman. (2007). Desain Model Pembangunan Kesatuan Pengelolaan Hutan (KPH) di Kabupaten Mamuju Provinsi Sulawesi Barat. Jurnal Perennial, 5(1) : 36-44.

Thies, B., Meyer, H., Nauss, T., \& Bendix, J. (2014). Projecting land-use and land-cover changes in a tropical mountain forest of Southern Ecuador. Journal of Land Use Science, 9(1), 1-33. https://doi.org/10.1080/1747423X.2012.718378

Turner, M. G. (1989). Landscape Ecology: The Effect of Pattern on Process. Annual Review of Ecology and Systematics, 20(1), 171-197. https://doi.org/10.1146/annurev.es. 20.110189.001131

Veisi, H., Khoshbakht, K., \& Sabahi, H. (2012). A participatory assessment of agro-ecosystem sustainability in Abesard, Iran. International Journal of Agricultural Sustainability, 11(1), 1-17. https://doi.org/10.1080/14735903.2012.676797

Yasmi, Y., Broadhead, J., Enters, T., \& Genge, C. (2010). Forest policies, legislation and institutions in Asia and the Pacific: trends and emerging needs for 2020. Asia-Pacific Forestry Sector Outlook Study II, Working Paper Series. FAO. https://doi.org/10.1017/CBO9781107415324.004

Yusran, Y., Sahide, M. A. K., Supratman, S., Sabar, A., Krott, M., \& Giessen, L. (2017). The empirical visibility of land use conflicts: From latent to manifest conflict through law enforcement in a national park in Indonesia. Land Use Policy, 62, 302-315. https://doi.org/10.1016/j.landusepol.2016.12.033 